This item was submitted to Loughborough's Research Repository by the author.

Items in Figshare are protected by copyright, with all rights reserved, unless otherwise indicated.

\title{
Cross-cultural and cross-national consumer research: psychology, behavior, and beyond
}

PLEASE CITE THE PUBLISHED VERSION

http://dx.doi.org/10.1108/IMR-03-2015-0092

PUBLISHER

(C) Emerald

VERSION

AM (Accepted Manuscript)

\section{PUBLISHER STATEMENT}

This work is made available according to the conditions of the Creative Commons Attribution-NonCommercialNoDerivatives 4.0 International (CC BY-NC-ND 4.0) licence. Full details of this licence are available at: https://creativecommons.org/licenses/by-nc-nd/4.0/

\section{LICENCE}

CC BY-NC-ND 4.0

\section{REPOSITORY RECORD}

Michaelidou, Nina, Nina Reynolds, Luke Greenacre, and Louise Hassan. 2019. "Cross-cultural and Crossnational Consumer Research: Psychology, Behavior, and Beyond". figshare. https://hdl.handle.net/2134/17788. 
Cross-Cultural and Cross-National Consumer Research: Psychology, Behavior, and Beyond

\author{
Dr Nina Michaelidou \\ Loughborough University \\ Professor Nina Reynolds \\ University of Wollongong \\ Dr Luke Greenacre \\ University of South Australia \\ Dr Louise Hassan \\ Bangor University
}

Globalization leads to a need to understand consumer behavior across national boundaries. The call for this special issue noted: "Consumers from different countries and cultures may be similar on some dimensions but differ on others. This provides researchers with the opportunity to explore how changes in multiple aspects of the cultural and national context can influence consumer theory." This special issue is particularly relevant given the blurring of geographic cultural boundaries and the reshaping of society though global flows relating to mediascapes, ethnoscapes, ideoscapes, technoscapes, and finanscapes (Appadurai, 1990). The blurring of boundaries and the associated emergence of a 'global consumer culture' (Cleveland and Laroche, 2007; Zhou et al., 2008) allows companies to standardize their branding and communication strategies. Nevertheless, meaningful cultural differences can still be found in consumer psychology and behavior across countries (e.g., Walsh et al., 2014).

The extent to which consumer behaviors are influenced by culture is worthy of study from different approaches. The social collective, biological and cognitive approaches discussed by Briley et al. 
(2014), each provide complementary insights into the role and function of culture on consumers. Given that the majority of theories used in the consumer discipline have to date been developed based on samples of consumers in Western nations (Arnett, 2008) there is still a major question as to the universality of consumer behavior theory. The evidence put forward by Briley et al. (2014) suggests that the assumption of universality is questionable. Thus, there is a need for additional scholarly attention on cultural differences in consumer psychology, behavior and beyond.

\section{Content of the Special Issue}

Our call for papers attracted 39 submissions which is somewhat reflective of the increasing scholarly attention cross-cultural consumer research is currently receiving. The objective of this double special issue was to extend the debate on the role of culture in consumer theory and examine psychological and other influences on consumer behavior in cross-cultural and cross-national contexts. The articles chosen for this special issue include studies that examine sub-cultures within a single country, as well as several that move beyond the dominant US/Western European consumer sampling frame. The topics investigated range from psychological investigations of consumer perceptions and motivations, to behavioral assessments of communication and purchase. Overall, the resulting nine articles in this double special issue provide new insights into the latest cross-national and crosscultural consumer research, which enhances theoretical and practical understanding across a varied set of contexts involving data from fifteen different countries.

The first article by Sudbury-Riley and colleagues is grounded in the area of cross-cultural global age research and focuses on self-perceived age in four countries, namely the UK, Germany, Japan and Hungary. The authors use a quantitative research design and collect data from 880 Baby Boomers to investigate multi-national measurement invariance of cognitive age which impacts consumer 
behavior and is related to values. The authors' findings provide support for the existence of a 'young at heart' culture in all nations examined in the study, and hence put forward the suggestion that a 'global consumer culture' based on being 'young at heart' may be emerging. The second contribution to the special issue, by Torelli and colleagues, investigates cultural patterning on power norms in consumers' evaluations of service providers. The authors focus on subcultures, and specifically investigate differences in injunctive norms applied by White Americans and Hispanics in service contexts, while at the same time examine the role of power salience. The research is carried out via three studies involving experimental designs. The authors report findings, which show cultural variations in injunctive norms that are applied to power-holders, while at the same time highlight instances where such norms are applied to consumer judgment in service contexts. The third article by Christodoulides et al. focuses on the area of brand equity aiming to contribute to the limited cross-national research on the concept. In particular, the authors examine the performance of Aaker's consumer-based brand equity conceptualization using data from 1829 consumers in three European countries, that of Germany, Greece and the UK. Christodoulides et al. find that Aaker's brand equity dimensions cannot be distinctively separated in all the national contexts examined. The fourth article in this double special issue by Weisfeld-Spolter et al. is driven by the debate on global consumer culture to examine the global multichannel consumer. The authors use data from three countries that of the US, Russia and Singapore to test a theoretical model purchase behavior. The authors results support the idea of convergence of multichannel consumer behavior within the contexts examined by the authors, thus yielding interesting implications for managers to influence specific stages of the buying process online. Further, the fifth contribution to this special issue on cross-cultural and cross-national consumer research by Newton et al. proposes a decision-making model that explains the co-adoption of three environmental behaviors such as sourcing electricity from green suppliers, purchasing green products and using public transport. The authors use a quantitative research design involving data from three countries namely Australia, the US and the 
UK. Newton et al.’s results suggest that personal benefits as well as consumer effectiveness are significant in motivating consumers' decisions to engage in coaction or co-adoption of environmental behaviors. Keh and colleagues’ article represents the sixth contribution to the special issue. The authors work focuses on online movie ratings in Asia markets and uses an experimental design with data collected from 4 markets that of India, China, the Philippines and Chinese Macau. Keh et al. conduct two experiments, and report that the volume and valence of online ratings influence consumers’ perceived risk and purchase intentions, while highlighting cultural variations, based on Schwartz (1992), across the four markets studied. Subsequently, the issue presents the work of Thøgersen and colleagues on consumer motives and attitudes towards organic food in two emerging markets, highlighting similarities and differences across the two emerging nations. The authors report that buying motives in both countries are similar and grounded on the specific characteristics of organic food, as well as to the belief that organic food is beneficial to the 'common good'. The eighth contribution to the special issue is by Jun and colleagues who examine consumer characteristics in the topical context of social networking sites (SNS). The authors use a quantitative design and develop a model tested via SEM with data collected from two countries that of Korea and the US. Results indicate that consumer innovativeness, the propensity to share information as well as concerns about privacy on SNS affect the intensity of SNS use, at the same time highlighting variations across the two national contexts. Finally, Siamagka and colleagues examine affective states and their impact on online brand perceptions using data from five countries. The authors test a theoretical model via SEM revealing that positive comparative affective states impact consumers' online brand perceptions; albeit the weight of impact differs across the different national contexts, hence yielding theoretical and managerial implications.

\section{Acknowledgements}


We would like to express our appreciation to all the reviewers who supported this special issue by providing constructive feedback to the authors' work. We would also like to thank the editor of the International Marketing Review, Prof. John Cadogan, for offering us the opportunity for this special issue and for the guidance he provided throughout the undertaking of this special issue. Finally, we would like to extend our gratitude to the editorial office for their excellent support.

\section{References:}

Appadurai, A. (1990), “Disjuncture and difference in the global cultural economy”, in Featherstone, M. (Ed.), Global Culture: Nationalism, Globalization and Modernity, Sage, London.

Arnett, J.J. (2008), “The neglected 95\%: Why American psychology needs to become less American,” American Psychologist, Vol. 63, No. 7, pp. 602-614.

Briley, D., Wyer, R.S., and Li, E. (2014), “A dynamic view of cultural influence: A review,” Journal of Consumer Psychology, Vol. 24, No. 4, pp. 557-571.

Cleveland, M. and Laroche, M. (2007), “Acculturation to the global consumer culture: Scale development and research paradigm”, Journal of Business Research, Vol. 60, No. 3, pp. 249-259.

Walsh, G.Shiu, E. and Hassan, L.M. (2014), “Cross-national advertising and behavioral intentions: A multilevel analysis,” Journal of International Marketing, Vol. 22, No. 1, pp. 77-98.

Zhou, L. Teng, L. and Poon, P.S. (2008), "Susceptibility to global consumer culture: A threedimensional scale”, Psychology and Marketing, Vol. 25, No. 4, pp. 336-351. 